\section{Some Theoretical Considerations on Caste}

Madhusudan Subedi

\begin{abstract}
Caste as a system of social stratification was an encompassing system in the past. There was reciprocal system of exchange goods and services. With time, occupation and mode of generation of livelihood of various caste groups changed, and the traditional form of jajmani system fizzled out. This paper provides an account of changing perspectives of caste relations in social science writing and political discourse. The discourse of caste has been shifted from ritual hierarchy and social discrimination to an instrument to mobilize people for economic and political gain.
\end{abstract}

Keywords: Affirmative action, identity politics, ritual hierarchy

\section{Introduction}

The theme in this article is social stratification and social inequality. This is not a new issue in sociology, but this article will focus on caste, its context and position in people's day-to-day life, relations among them, and the changes taking place in those relations. I believe that stratification and inequality is the most important issue in sociology, and the conditions of castes have been crucial when discussing Nepal's social structure. My impression is that there has been a major change from treating caste as a rigid stratum to the current perception of caste as 'identity to negotiate power and resources'. In this article, I mainly focus on some key theoretical debates on caste and its changing context.

Caste has been discussed in classical Hindu texts, in micro level ethnographic accounts, and in large-scale surveys of attitudes and perceptions, and caste-based mobilizations. What is caste and how can it be defined? What are its core descriptive dimensions? How could it survive for so long and what keeps it going even in modern, contemporary times (Jodhka 2012)? Although these questions appear to be rather simple and obvious, the rich literature dealing with these issues do not offer any straightforward answers.

Social stratification is the ordering of social differences based on a set of criteria or just one single criterion (Gupta 2000). Caste, class, race, ethnicity, and gender are some of the pertinent categories of social hierarchy and differentiation in many societies. The term 'caste' means different things when used by different people in a variety of situations. What people mean by caste in everyday life is different from its meaning in the traditional literature or from what people consider to be its traditional and orthodox meaning (Béteille 1965, p. 45). Sometimes people mean 'caste' to be a small and more or less localized group, but the same word also can refer to a collection of such groups. This article starts with sociological and anthropological understandings of the caste system and its variations.

\section{Issues in the Theoretical Discussion of Caste Systems}

Caste may be defined "as a small and named group of persons characterized by endogamy, hereditary membership, and a specific style of life which sometimes includes the pursuit by tradition of a particular occupation and usually associated with a more or less distinct ritual status in a hierarchical system” (Béteille 1965, p. 46). Berreman (1967, p. 70) has defined the caste system as a "system of birth-ascribed stratification, of socio-cultural pluralism, and of hierarchical interaction”. With Sinha's words (1967, p. 94), “caste is a hierarchy of endogamous groups, organized in a characteristic hereditary division of labour". Hutton (1946) describes a functional 
view of caste system for individual members, community functions, and function for the state and society as a whole. Ghurye (1950) gives a comprehensive definition of caste. According to him, the six main features of the caste system are: segmental division of society, hierarchy of groups, restriction of feeding and social intercourse, allied and religious disabilities and privileges of the different sections, lack of unrestricted choice of occupation, and restriction on marriage. Endogamy is the stable feature of a caste system. However, in recent years, inter-caste and inter-religious marriages have taken place (Sharma 2007)

Sociologists and social-anthropologists use the word 'caste' in two different senses. On the one hand it is used without any particular geographical limitation to denote the type of class system in which hierarchy is very sharply defined and in which the boundaries between the different layers of the hierarchy are rigidly fixed (Leach 1967, p. 9). A ruling class may be described as a caste when class endogamy is strikingly obvious and when the inheritance of privilege has become narrowly restricted to members of that caste in perpetuity. This kind of situation is likely to arise when the ruling group is distinguished from the inferior group or groups by large differences in the standard of living or by other easily recognized labels or conditions (Leach 1967, p. 9). Thus, it is usually easy to locate an individual in his/her stratum, and when this is done, one knows how to deal with him/her even without knowing him/her personally. If $\mathrm{X}$ belongs to the first stratum and $\mathrm{Y}$ to the second one, $\mathrm{X}$ will be considered socially superior to $\mathrm{Y}$, irrespective of their personal qualities, and be treated accordingly.

The other use of the word 'caste' is to specifically define the social organization found in traditional regional societies in India and within adjacent Hindu and related populations in Bangladesh, Nepal and Sri Lanka (Leach 1967; Hutton 1969; Dumont 1980; Marriott and Inden 1985;), and which to a large extent have survived to the present day.

Clearly there has been a long debate in the literature over whether the caste system is a unique social phenomenon or simply one manifestation of general processes of social stratification. (Leach 1960; Sinha 1967; Berreman 1968; Appadurai 1986; Gould 1990). Whether caste is best considered as a cultural or a structural phenomenon is a question much debated by sociologists (Leach 1960, p. 1). Max Weber, for example, stated categorically that “... caste is the fundamental institution of Hinduism” (cited in Leach 1960, p. 2). He implies thereby that caste is a specifically cultural concept, but he proceeds with the remarks that "there are also castes among the Mohammedans of India ... Castes are also found among Buddhists" (ibid.). This contradiction leads to an inquiry into the nature of caste, but here Weber's standpoint keeps shifting. Having started by implying that caste is particularly a Pan-Indian phenomenon, he continues with a discussion of caste analogues in non-Indian contexts. Similarly, those 'diffusion' writers who manage to find historical examples of caste behavior all the way from Ancient Egypt to modern Fiji (e.g. Hocart 1950; Hutton 1946), start by assuming that caste can be defined as a list of ethnographic traits characteristic of Hindu India and then slide into the assumption that caste refers to certain features of a social structure (Leach 1960, p. 2).

The work of Dumont and Pocock, Marriott and Inden, their students, and the views of Leach have stressed that caste is to be defined in terms of its Hindu attributes and rationale, and therefore, is unique to Hindu India or at least to South Asia (Berreman 1968, p. 333). Bailey, Barth, Béteille, Berreman, Passion, De Vos and Wagatsuma have stressed that the caste system is to be defined in terms of structural features that are found not only in Hindu India but in a number of other societies as well (Gould 1990, p. 2). The latter group of scholars tend to take the view that cross-cultural comparisons can be effective only on the social structure level and not in terms of cultural patterns and value systems (Sinha 1967, p. 93). Those who hold this view find caste groups in such widely scattered areas as the Arabian Peninsula, Polynesia, North Africa, East Africa, Guatemala, Japan, aboriginal North America and the contemporary United States. The following section highlights these two schools of thought. 


\section{Caste as a Hindu Social Construct}

This school of thought understands caste as a Hindu social construct, a total symbolic world, unique, self-contained, and not comparable to other systems. Most of these theorists would agree with the classic definition given by Bouglé, who wrote that the spirit of caste unites these three tendencies: repulsion, hierarchy and hereditary specialization. Here controversies are primarily about which of these aspects is stressed.

Those who argue that caste as a unique phenomenon have viewed it within three sub-categories, that I have termed after Louis Dumont's description of the Hindu caste system: Pre-Dumontian, Dumontian, and Post-Dumontian.

\section{Pre-Dumontian Views of the Hindu Caste}

When Max Weber prepared his study of religion and society in India, as a part of his famous treatise on the sociology of religion, all the major Sanskrit scriptures of Hinduism had been made available in high quality translations, through the efforts of orientalists. Weber was well acquainted with these sources, and he was also familiar with the census reports, which he described as "scientifically excellent" (Weber quoted in Lunheim 1993, p. 64).

Weber considered the Indian society an "ideal type" of his general notion of belief systems as main determinants of the social and economic structure (in contrast to the Marxist view). In India the link between religious beliefs and social differentiation was direct and explicit, whereas in western society the connection is indirect and obscure. Hence caste appeared, to Weber, as an integral aspect of Hinduism, and he started out by declaring this central notion quite axiomatically: 'before any things else, without caste there is no Hindu" (Weber quoted in Lunheim, 1993, p. 64). Weber then went on to explore the alleged parallel between caste and guild. He concluded that there was much more to caste than mere occupational specialization. For instance, the guilds of the European Middle Ages were not closed, endogamous social units like castes. Therefore, an extensive analogy between caste and guild missed the essential features of both phenomena. This served to corroborate the major point Weber wanted to prove. The formative forces underlying caste are not to be found in economic or material conditions, but in ideology, i.e. religion, in the shape of Hinduism.

Weber construed caste as a special and extreme case of status groups. Whereas a class was considered as being constituted by individuals in similar economic positions, the cohesive force of a status group was honor and prestige. Identity was created and maintained by imposing restrictions on social intercourse and marriage with those who "do not belong", primarily those being inferior in terms of honor and prestige. In the Indian caste system this mechanism was developed to the extreme with strict caste endogamy and the religious concept of pollution. Caste was thus a more perfect variety of closed status of class.

The interplay between class and the Protestant Ethic ideology is a main point in Weber's analysis of industrialization. He explained industrialization by applying John Calvin's religious beliefs that an after-life could be secured by hard work, self-discipline, and thrift. A similar Hindu ideology of rebirth prescribes strict adherence to one's caste duties and prospect of transcendental rewards in subsequent reincarnations. In Weber's synthetic construction of caste and Hinduism, the karma doctrine was the key principle of cosmic reality.

How was it that the karma theology, which is found in several ideologies other than Hinduism, combined in India with caste to form such a peculiar structure? In his analysis, Weber was rather uncertain, but pleaded in favor of a notion of racial differences in ancient India as the main determinant of the evolution of caste. Weber did not elaborate the comparative perspective explicitly, but the juxtaposition was symbolic for how an understanding of the caste system influenced sociological thought about the distinctive characteristics of western civilization. 
Célestine Bouglé’s essay stands as an important landmark in the intellectual history of caste. In the essay's introduction, Bouglé lists what he considers the three defining principles of "the spirit of caste" (Lunheim 1993, p. 66):

Hereditary specialization: The hereditary association of caste and a specific trade or profession.

Hierarchy: Personal status, as rights and duties, is unequally divided and determined by the rank of the group to which one belongs.

Repulsion: The phenomena of mutual repulsion between social groups, division into opposed fragments, isolation at the group level, and mechanism to prevent alliances and relations across the group boundary, like endogamy, pollution concepts, and food taboos.

These three features combined constitute the defining properties of caste. Taking this definition as a starting point, Bouglé discussed if caste ought to be considered an exclusively Indian (Hindu) phenomenon or not (ibid, p. 66). He concluded, like Weber, that many social systems, including the western ones, exhibit castelike properties, but that "the spirit of caste" in its fully developed sense, is found only on Indian soil (Lunheim 1993, p. 67). Finally, Bouglé attributed the hierarchical aspects of castes to the ritual and religious dominance of the Brahmans. Furthermore, he is among the scholars who recognized, or at least emphasized, the crucial distinction between socio-religious rank and secular power in Indian society - thereby initiating a heated discussion in the anthropology of caste. Louis Dumont considered himself to be the first one to have been influenced by Bouglé's essays on caste (Dumont 1980, p. 30).

\section{Dumont on Caste}

Louis Dumont was a French scholar and the author of the famous book on caste, Homo Hierarchicus, originally published in French in 1966 and translated into English in 1970. The book constructed a textually informed image of caste, portraying two opposing conceptual categories of purity and pollution as the organizing principle of caste structure and hierarchy (Dumont, 1980) ${ }^{1}$. These unique core principles of caste hierarchy, according to Dumont, are observed in scriptural formulation as well as in the everyday life of all Hindus (understandably in India). The Dumontian notion of caste puts hierarchy at the centre and assumes that this more or less (coiled in the notions of purity and pollution) prevails all over Hindu populations. Dumont's concern was with the traditional social organization from a comparative theoretical point of view.

Dumont (1980) argued that the introduction of the idea of structure was a major event in social anthropology. The essential challenge for contemporary thought was to rediscover the meaning of the whole or systems, and structure provided the only logical form as yet available to this end. Dumont argues that a structural analysis is concerned with the relationships, not substance-relationship parts and between parts and totality. For Dumont, it was legitimate to include in the caste system only what we could call inter-caste relations, and not intra-caste relations. He was critical of contemporary anthropologists who "take the part of the whole" and who did not address sufficiently inter-caste relations or the total system. Dumont also criticized anthropologists who had studied only one aspect of the system such as jajmani system or food transactions between castes.

For Dumont, the dominant principle of Hindu caste system was hierarchy - hierarchy, of course, of a religious, rather than of a political, sort. Other key principles were purity and impurity, also being religious, and interdependence by which parts are interrelated, and related to the whole. Thus, Dumont said that "the Indian caste system is not individualistic; it emphasizes its totality, not its

\footnotetext{
${ }^{1}$ Dumont's principle of ritual hierarchy operates on two levels, p. the opposition between the Brahmin (as the very epitome and essence of purity) and the "untouchable" (as the carrier of impurity); and between the Brahmin (as the figure of sacred/ritual status) and the king (as the figure of the temporal/secular power). Since the pure always necessarily encompasses the impure, at least at the level of the ideology (if not at the level of the fact), the Brahmin is placed at the top of the hierarchy. And this is so not only in relation to the progressively receding states of less purity (or more impurity) as embodied in the person of other castes, but also in relation to the king or the holder of the temporal authority.
} 
individual members” (Dumont 1980; Kolenda 1981). This religiously based conception of hierarchy is different from its meaning in other parts of the world.

For Dumont's purpose, the most important feature of the Varna writings was the superior status of the Brahman over the Kshatriya on the basis of the Brahaman's monopoly of the offering of sacrifices. Brahman and Kshatriya are interdependent and superior to the other two Varnas. It is a matter of an absolute distinction between priesthood and royalty. The Brahman performs sacrifices and never rules; the Kshatriya rules, but never performs sacrifices. But the Kshatriya is dependent upon, and inferior to the Brahaman. Dumont indicated that the disjunction, in the dominant Indian tradition, between priest and king is different from those societies in which the king is also a high priest (ancient Egypt, for example), as well as from modern Western societies where the political is both completely secularized and absolutely autonomous from religion.

Dumont associated man's purpose in life, for instance as described in the ancient Hindu law books, the Dharmasastras, with the Varnas. There are three 'human goals': dharma, artha and kama, (duty, profit and pleasure). The analogy with the hierarchy of Varna is apparent: dharma corresponds to the Brahman or priest, artha to the king or Kshatriyas, the temporal power, and kama to the others. Brahman counsellors know the dharma advice to the king; it is the king's duty (dharma) to protect the people in exchange for grain payment. Dumont defined Dharma as 'the holistic idea of order'. This is to be seen in the jajmani system that is oriented toward the welfare of all.

Dumont rejected the idea that morphological similarities of ranked strata are enough to make other systems into caste systems. On these grounds he argued that the society in Sri Lanka is built upon 'quasi-caste rather than caste proper', since Brahmans have never been numerous in Sri Lanka and the Buddhist concept of kinship rejects the Brahman-Kshatriya duality.

Dumont's notion was criticised as it failed to explain the social change, dynamism and individualistic strivings that can and do take place even within the orthodox Hindu way of living. The most important criticism, among others, is methodological. Gerald Berreman (1999) has argued that Dumont had listened too much to Brahmans and their religious texts, which, in Berreman's argument, offer an artificial, stiff, stereotypic and idealized view of caste. Gerald Berreman pointed out that the principle of Brahmanical hierarchy (the one reconstructed by Dumont) is not uniformly followed by all Hindus. He also criticized the Dumontian notion that power and economic factors are distinct and epiphenomenal to caste and asserts that the power status opposition is a false dichotomy in the context of caste - the two are inseparable.

Dumont was concerned essentially with the structure of value and not with the structure of interest (Béteille 1991, p. 132). It can of course be argued that Dumont's observation apply to the traditional and not to contemporary India. Tambiah made a critical note and asked what happened to Homo Hierarchicus in Britain:

The Rose Report informs us that Indians (and Pakistanis) appear to live with discrimination at the political and occupational level, while preserving the autonomy of their social life. Hindus have long lived in political subordination while thinking their religious and social life superior to that of their overlords. In contrast, West Indians, the heirs to an originally unequal racial situation, devoted to the idea of an egalitarian and democratic Britain, are deeply disappointed that some are more equal than others (1972, p. 835).

Whatever Dumont might have said about caste as a method of studying Indian society, he did support the caste system and its allied sanctions. For him caste was 'social' as religion is 'social' for Radcliffe-Brown and Durkheim. Dumont advocated the continuity of the caste system by emphasizing its functions for individual members, for a group, and for the entire Indian society or state. Such an advocacy during the British days had led to the promotion of their colonial interest in India. However, this view stands contradicted when they make a sharp distinction between caste and class. Class is 
considered as a characteristic feature of western societies, being characterized by its emphasis on democracy, individualism and openness. On the contrary, caste, as a core-feature of Indian society, is defined as an archaic institution lacking democracy, individualism and freedom.

Dumont brought in a mystic aura around the caste system. Why did he consider caste as a cultural form of social inequality? Is inequality based on racial criteria not an extreme form? Continuing monarchy in England or depriving women from contesting to become President in USA were equally retrograde and archaic practices, but Dumont forgot them conveniently, not declaring them as extreme types of institutions.

\section{Post-Dumontian Views of Hindu Caste}

McKim Marriott (1976) advocated an interpretative framework based upon 'coded bodily substance' concepts to analyze the Hindu caste system, slightly different from the one proposed by Dumont. Taking issue with western dualism, Marriott proposed an approach called ethno-sociological, transactional, interactional, monistic, and substance codes based. He saw caste as built on a series of notions concerning bodily substances and inter-personal exchanges. Based on the study of the Konduru village in the Andhra Pradesh, India, he introduced the interactional approach focusing on who is willing to accept food, water, etc., from whom as a sign of relative status. Those of lower ranks are supposedly willing to accept food from those of higher ranks, but not vice versa.

The Brahman caste appears nowhere as receivers of any lower forms of substance-code, such as ordinary payment for services, wives from a lower caste, or ordinary cooked food. Brahmans typically accept substance-code only in a very perfect form, such as gift of a piece of land, money or grain. Brahmans take the highest position through their own divinity, through their exclusive exchanges with still higher, more generous goods, and through their great gifts to other-terrestrial men - cosmic knowledge in the form of substancetransformative ceremonies, teaching and advice (Marriott 1976).

Castes that follow, according to Marriott, some kind of maximizing strategy include Rajput and their allies which try to increase a symmetrical exchange through land control, labor, or food distribution, as well as maximizing strategies of marriage, descent and diet to achieve the greatest quality and potency in substance, action, and group substance-code. Those whose tactics include minimizing the number of relationships in which they exchange cooked food, are identified as skilled artisans. The minimizing transactional strategy is designated by the classical name Vaishya, being those with productive power to grow grain, rear cattle, trade, supply butter, and pay taxes. The groups with more "receiving" than "giving" relationships fall into two occupational categories: Both barbers and leather workers take food as well as bodily substance-codes directly from patrons of many castes.

Perhaps the most important aspect of these strategies is that it makes it easy to find out the local caste ranking. However, does eating the proper food symbolize religious purity or does it actually make a person pure? Knowledge is another important component as a symbol of high status and sacredness, and is seen as partly independent of purity and pollution per se. The strategy is unable to answer the questions addressed above.

Dumont's dualism, hierarchy and purity of caste as a religious phenomenon have been challenged by Gloria Godwin Raheja (1990) based on fieldwork in Pahansu, India, an Utter Pradesh village dominated by landowning Gujars. The Gujar caste hold 98 percent of all arable land in Pahansu and are hence, by virtue of economic strength, the dominant caste. Raheja suggested that castes were interrelated by three different orders that were actualized and emphasized to various degrees depending on the contexts. The 'hierarchical ordering' constituted by the principle of ritual purity, has the Brahman and the Bhangi (sweeper) as its extreme points (Raheja 1990, p. 3). This ordering corresponds to the traditional conception of caste rank. 
Inter-caste relationships and Gujar dominance are, however, constituted primarily by dan prestations made in and through jajmani relationships. Jajmani relationships entail an ordering of mutuality in which the members of the service castes receive a share of the harvests, "payment" for loyalty and service rendered to their Gujar patron (jajman). Although asymmetrical, and linked with power and economy, jajmani relations do not define a hierarchical order among castes.

The ritually most significant ordering principle in Pahansu is the 'ordering of centrality'. She argues that sovereignty has political and religious aspects, the Gujar having the crucial function of distributing evil and inauspiciousness through their dan prestations. In their roles as someone who "sacrifices” (jajman), it is right for Gujars to give dan and duty to "others", mainly the members of other castes, including those who are hierarchically superior, and which must accept (Raheja 1990, p. 88). Through dan prestation inauspiciousness is transferred from the giver to the receiver in non-reciprocal relations that express Gujar dominance. Dan prestation are related to notions of the social world as a closed, circular system with regard to inauspiciousness. The luck and wellbeing of one means the misfortune and suffering of another: one man's meat is another man's poison.

The duty of caste members to accept dan from their Gujar jajmans, and thereby absolve their sins, is a ritual expression of their subordination. In this respect all other castes than Gujars, Brahmans along with sweepers, carry out virtually identical ritual roles in relation to the jajmans. Raheja (1990) saw the dominant landcontrolling caste at the centre of the local jajmani system. Its ritual centrality, rather than superior purity of Brahmans, makes the system operate. Raheja's study clearly demonstrated the multi-dimensionality of caste in a Hindu society.

Moreover, although hierarchy is evident in inter-caste relationships, Raheja rejects Dumont's claim that there is one ideological principle and one type of relationship. Instead, she claims that differently valued relationships come to the fore depending on the context. The "centrality" of the Gujar in the exchange structure when they distribute inauspiciousness to "others" is one example of this. However, in the different contexts defined locally as transactions between "one's own people," relationships between the very same castes are conceptualized as sharing and "mutuality. Therefore, it can be said that Brahmans always do not possess high rank and purity, and in such cases they are regarded as polluted and dependent. Whereas Dumont pointed out that Brahmans are always high ranking and considered as pure. These two visions about Hindu caste clearly contradict each other, and clearly show that there is not a uniform concept of caste within the Hindu value system. Raheja's view of centrality is nearer to the Marxist view of social class in which those who control the means of production are regarded as superior to others, than to the Hindu concept of purity and pollution.

In spite of the variation in their empirical reasoning, all three views follow the essentialist paradigm where society is divided into a set of rigid, hierarchical groups bound together in an immutable bond, justified in terms of moral superiority of the clean caste to those considered unclean (Mitra 1994). This type of nation state, in my view, remains ontologically and politically inaccessible to its own citizens, representing an injustice against the fellow citizens (Berreman 1991). By virtue of this situation, it generates enormous conflicts and a constant threat to status quo. It is suppressed whenever possible, but the process of suppression is difficult and will never completely be effective.

Dirks (2001) argues that the most prominent and related transformed traditions are kingship and caste. In pre-colonial SouthIndia - as in other parts of India - local kings were part of a dynamic network of major and minor kings struggling for dominance in warfare as much as in worship and the support of temples. Kingship was an institution involving the political and religious domains. The social hierarchy, Dirks argues, at that time was not so much on the ideology of the pure and the impure as on the institution of the king. Ruling was about people not territory. A system of gift giving was common. The king bestowed honours, privileges, and tax-free land on 
all sorts of institutions and people, such as his militia affine, castes, priests, and village heads, thereby securing their loyalty and support as well as his own position.

The British, Dirks argues, did not understand how this system worked and what it was all about. In effect, they froze kingship by taking away the political and dynamic aspect and turning it into a theatre state, a hollow crown. He emphasized that the colonial project was not one homogenous design of planning and insight but rather a matter of unintended consequences. Caste replaced the crown that came before. Caste became the colonial form of society; it justified denial of political rights to Indian subjects (not citizens) and explained the necessity of colonial rule (Dirks 2001, p. 16). And caste became the focus of progressive movements and debates - both local and national - about the character of post-colonial politics.

\section{Caste in a Comparative Perspective}

Caste as a structural phenomenon is considered as a category or type within a general theory of social stratification, comparable in many respects to hierarchical organizations elsewhere. In this vein, Berreman (1972, p. 197) argued that "to define caste in terms of its uniquely Indian attributes eliminates or at least diminishes its use as a cross-culturally comparable phenomenon." He preferred to define caste more broadly in order to include, for the purpose of comparison, similar systems of social stratification that occur in other cultures. Berreman argued that a caste system resembles a plural society whose discrete sections are all ranked vertically. Indian caste, therefore, is analogous to social structures elsewhere in which rank is ascribed, such as, for instance, racial differentiation in the United States.

Comparative social theorists have generally placed caste systems not as a unique religious ideological or structural category but as a matter of social differentiation and social stratification. Among the anthropologists studying caste in India, there exist different theoretical approaches, including those (Berreman 1972, Bailey 1957, Beteille 1965, Quigley) who regard it as an extreme form of social stratification, comparable with other forms of inequality based on social classes, wealth or political power. This approach emphasizes that caste system are held together by power concentrated in certain groups (the landholding and dominant caste), more than on a general consensus among the population.

Quigley (1999) focuses caste in terms of bounded groups and argue that very strict separation and endogamy only operate in particular circumstances and for particular groups. Those who aspire to dominance, have to define themselves as this is always an inherently fluid business. Castes are always relatively, rather than absolutely, bounded. Quigley argue that one way to begin explaining caste is to say what is not - that is to see it in comparative perspective.

Berreman (1967) argued that caste is a peculiar institution with peculiar consequences. He suggested a more comprehensive approach that allows cross-cultural comparisons without sacrificing cultural factors and distinctive patterns of social integration. Accordingly, "a caste system occurs where a society is made up of birth-ascribed groups which are hierarchically ordered and culturally distinct. The hierarchy entails differential evaluation, rewards, and association" (Berreman 1967, p. 48). He wanted to analyze what caste systems are, how they work, and what they do to people. When viewed comparatively and structurally, caste systems have customarily been described as systems of stratification - rigid, birthascribed, permitting no individual mobility, but nevertheless examples of ranked aggregates of people.

Comparative social theorists argue that every system of social stratification allocates power and privilege in the society in which it occurs, and most, if not all, such systems are associated with some ranked division of labor that promotes interdependence. Caste systems are systems of social stratification that, although unique in that they are based on birth-ascription, share the general attributes of such systems. Berreman (1991) argued that analyses of caste systems often have overlooked that they are more than simply rigid systems of stratification. Thus, castes are recognized as groups that usually have specific names, and they are in some ways interdependent. Between 
castes there exist barriers to social intercourse, cultural differences, and differential degrees of power and privileges. Associated with caste in many and perhaps all instances is a degree of occupational specialization (Berreman, 1972). They are also systems of cultural pluralism, maintained by enforced differential association among culturally distinctive groups.

The most striking similarities among caste systems are the social relations and patterns of interaction. There are numerous rules and restriction on marriage, on sex relations, on living together, on eating together, on sitting together, and on a variety of other forms of interaction symbolic of social inequality (Berreman 1967, p. 64). He argued that the concept of caste was applicable anywhere outside Hindu India, and usefully could be applied to societies with hierarchical endogamous sub divisions where membership is hereditary and permanent, wherever they occur (Berreman1979, p. 13). He further stated that the literature on caste in India, the race in America, on the Burakumin in Japan, on specific societies such as Rwanda reported by Maquet, and South Africa reported by van de Berghe, provide a starting place of a comparative study of caste.

Jacques J. Maquet (1970) described the tri-partite system, comparing three different groups among the Rwanda people: Tutsi, Hutu, and Twa. The immediately noticeable differences among these groups occur in their activities, their social statuses, and their physical types (Maquet 1970, p. 95). To be Tutsi, a Hutu or a Twa gave an individual a different status in society. Birth ascribed social status and occupation, marriage endogamy, and food transaction rules are very near the model of a caste. Therefore, it can be said that Rwanda strata are more castes than classes.

There are studies which have found caste among Muslims, Sikhs and Christians also. In a study of the Pathan of Swat, North Pakistan, Fredrik Barth (1960) described social stratification, and argue that the concept of caste is to be useful in sociological analysis and its definition must be based on structural criteria and not on particular features of the Hindu philosophical scheme. He regarded caste as a system of social stratification and concluded the principle of status summation seems to be the structural feature which most clearly characterizes caste as a system of social stratification.

Barth compares the system of social stratification among the people of Swat with Hindu caste system. Although the people of Swat are Muslims, Barth considers their division into social groups known as qoum similar to castes. The population is divided into various qoums that strongly resemble Hindu castes. Following the basic characteristics of Indian caste system, Barth postulated the patronclient relationship as the basis of the caste system. According to Barth, the Pathan system of patronage and the Hindu jajmani system are similar, where the lower status groups pay service to the higher groups. Each qoum are ranked by status, and high portions of the marriages are endogamous. In Swat, as in Hindu societies, the notion that pollution derives from body processes marks off certain castes as occupationally polluted. The indigenous polluted castes include washerman, sieve-makers, and dancers (Barth 1960) who are similar to India. This similarity, he points out, is a matter of structure rather than of culture.

In Barth's essay, caste was analyzed not as a set of ritual groups, but as a pattern of social stratification. Caste systems are considered to be characterized by the relatively high degree of congruence between the various status frameworks found in the community, with their hierarchies, and the hierarchy of caste categories (Barth 1981, p. 35). He further argued that the model for social identities should be composed of the silent features of the life circumstances for different caste at different times.

In another study of Fredrik Barth (1993) of Bali-Hindu people in Indonesia the 'basic division of population is that of caste' (Barth 1993, p. 31). This provides a different picture than the one of Hindu caste in Nepal and India. On the one hand, people are divided on the basis of the Warna (sanskrit) system, and on the other hand, caste is not a very silent feature of their everyday life and contemporary social relations. Many aspects of caste behavior are no longer observed (Barth 1993, p. 233). Level of seating and head elevation are no longer respected by the general public, even in the context of formal 
ritual. Endogamy is disappearing, so that even high caste girls are increasingly marrying down, and wealth and modern education are far more significant assets than high birth (ibid.). He further wrote that (ibid., p. 235) "caste in North Bali exhibits a confusing features" and provides similar problems about purity and pollution. These two brilliant studies of Barth provided the clear picture that there are more similarities of the Hindu caste in the non-Hindu area (Swat), while there are Hindus in Bali without traditional types of castes or Varna rights and duties. It can be said that Barth's generative models see social reality as an emergent phenomenon (Tambiah 1972). According to Sharma (2007), Muslims in India are divided into groups closely parallel to the caste system and notions of pollution and untouchable are found among them. Caste groups are found even in Sri Lanka, where Buddhism has been the religion of the Sinhalese people. Examples of similar caste systems are also reported from Burma, Japan and some other countries (Sharma 2007).

The Marxist approach to the study of caste has been applied with successful results in India. André Béteille’s (1965; 1991) important study in India introduced a new system in which lower castes have some political and economic power. According to Béteille, "the caste system is clearly a hierarchical system, although the nature of this hierarchy may be difficult to ascertain beyond certain broad terms. Landowners, tenants and agricultural labourers (of the same caste) also constitute a hierarchy” (Béteille 1965, p. 4). In the past, the division of a village was dominated not only by rituals, but also economic and political life. Today, there are many areas of life which are becoming progressively "caste free". Thus, landownership, occupation, and even education are not to some extent dependent upon caste. Today, the education system is far more open both in principle and practice. Education not only enables to compete on more equal terms with the Brahmans for white-collar jobs, but also provides them with more equal chances of political participation. In the towns and cities, white-collar jobs are relatively caste free (ibid.).

\section{Caste, Social Inequality and Marginalization}

Marginalization is the process by which established or emerging elites create superior versus subordinate/dependent socio-economic relations through manipulations of labor and distributions of social resources. In the caste-based society, high caste groups promoted their own advancement and initiated various economic changes at the community and regional levels that effectively marginalized the people in several important ways. For instance, as rising elites begin to accrue power, privilege and status, they draw increasingly economic dependent sectors of the population into important production roles or labour-intensive group activities. Arnold (1995) argued that if rising elites learn to control the information or technology critical to economic success and thus orchestrate network of interdependencies that limit power outside their small circle, then non-elites become marginalized from positions of substantial political or economic influence. This process establishes the foundation for permanent social inequality. Important potential sources for emerging elite power include, most fundamentally, control over human labor, but also over information, and/or transportation.

The ability of dominant groups to bring more and more labor under its control resulted rather quickly in exaggerated wealth inequities and higher social positions for some. Higher caste groups gained considerably more power, wealth and influence than the lower caste groups, thus bringing them higher economic status. The Dalits were forced to continue their work to sustain food, clothing and shelter. Men continued to work for wages or jajamani systems and the households became increasingly stratified based on caste identity. Dalit women continued to provide subsistence in traditional ways and thus supported the men, who provided most of the household's income. The role of some upper caste household members in supporting an increasingly wage-based (and less subsistence oriented) household economy as male pursued income from the outside, may have a counterpart in internal changes within agricultural societies. 


\section{Caste and Social Change}

Commenting on the nature of change taking place, G.S. Ghurye as early as in 1932, argued that attacks on hierarchy started with the rise of non-Brahmin movements in the southern provinces in India. These mobilizations generated a new kind of collective sentiments and the feeling of caste solidarity. M.N. Srinivas developed this point further. Focusing specifically on the possible consequences of modern technology and representational politics, both of which were introduced by colonial rulers in India, he argued that, far from disappearing with the process of modernization, caste was experiencing a 'horizontal consolidation'. Commenting on the impact of modern technology on caste, Srinivas wrote:

The coming in of printing, of a regular postal service, of vernacular newspapers and books, of the telegraph, railway and bus, enabled the representatives of a caste living in different areas to meet and discuss their common problems and interests. Western education gave new political values such as liberty and equality. The educated leaders started caste journals and held caste conferences. Funds were collected to organize the caste, and to help the poorer members. Caste hostels, hospitals, cooperative societies etc., became a common feature of urban social life. In general, it may be confidently said that the last hundred years have been a great increase in caste solidarity, and the concomitant decrease of a sense of interdependence between different castes living in a region (1962, pp. 74-75).

Based on the empirical materials from six villages in Rajasthan, Sharma (1969) mentioned that two types of changes had taken place in the village community. The first one could be described as a structural change, which included processes like the abolition of the Jagirdari and Zamindari systems, the introduction of adult franchise, Panchayati Raj, and the co-operatives, etc. The second type of change included peripheral changes, such as the establishment and construction of modern schools and roads, and migration.

The process of modernization in a caste starts when the ritualistic considerations of caste stratification become considerably less effective, and new attributes are substituted to maintain status. For example, the upper castes, in general, put more emphasis on achieving higher education, higher income, white-collar occupations, and positions of power and influence than on reinforcing their ritualistic endowments.

The systems of Jagirdari and Zamindari in the past vested a kind of economic power in the hands of the upper castes, which reinforced their ritual status and its accompanying privileges and obligations. The abolition of these institutions has thus affected the role of ritual superiority in the village's social stratification system. Many aspects of the Jajmani relations have been weakened; a variety of ritual obligations are now becoming obsolete. Consequently the upper castes are finding new means through education, political participation, and mechanization of agriculture, etc, to compensate the loss of their traditional social status. On the one hand, this leads to adoption of new skills and technologies, and on the other hand, it weakens the role of traditional values and rituals in their social and cultural life. Thus, what is modernization from one point of view also turns out to be de-sanskritization from another.

Education is another factor through which some castes that previously were not dominant in a village, have improved their status. In such cases, the position of the educated families compares even more favorably with that of the former dominant castes families whom they have now replaced. Mobility in caste structure is evidenced by a sense of caste solidarity that exists in the minds of the people of the various castes. This sense of caste unity prevails more among the Dalits than the upper castes.

There is another level at which this statement needs to be approached in order to gain an insight into the exact nature of change in the caste-occupation nexus. For instance, what has happened to ancient occupations that have survived changes in economic structure, 
for instance, the priest in temples, scavengers, traditional moneylenders, and several of the agricultural jobs? Are these jobs still performed by castes to which they were traditionally allocated? Or, is the reshuffling of the deck total, that is, is the modern occupational structure randomly distributed across castes? Is it likely that here we may find more change than continuity.

Also, what happens to those who have left traditional jobs, either because those occupations themselves are vanishing or because of the quest for better jobs? Is it true that lower castes tend to get absorbed into lower paying and less prestigious modern occupations and higher castes get concentrated at the upper end of the modern spectrum (Despande 2011)? It is possible then, that the link between caste and occupation can be broken and yet the overlap of caste and class can be very strong. If this is true, the contemporary situation could be regarded as a permutation of an earlier caste structure where the link between caste and occupation may be strong for some castes, weak for others, but the association between caste and status or, more correctly, between caste and privilege, persists, albeit in a different form. It can never be argued that the cumulative advantage of upper castes has been so strong that they no longer need an institutional structure of hereditary reservations in order to perpetuate their privilege. This is one more instance where a rigorous social and economic investigation into the caste composition of the occupational structure can help drive an objective, larger picture of the nature and degree of change. Does this suggest that caste today simply captures class? This is a perennial question, confounded by the fact that the overlap between the two is very strong. However, my belief is that they are distinct, despite the very large overlap.

One of the most significant contributors to the study of caste, Srinivas (2003) argued that the subsistence economy of rural India, dependent on jati-based division of labor, is the 'essence of caste'. As this is rapidly breaking down, it 'augurs the end of social order which has continued for 2000 years or more'. He suggested that production will become freed from jati-based division of labor, economic relation will payments become autonomous, and payments in goods will be replaced by cash. Indian rural society will move, or is moving, from status to contract.

The reality, as any serious observer of India can tell, is that caste has changed tremendously over time. So much so that many, especially those with exposure only to the metropolitan cities, believe for all purposes that it is virtually dead. It would be argued, for instance, that the fewer overt instances of untouchables in urban areas than in the more traditional rural settings, demonstrates that caste is increasingly irrelevant. However, that should be the least expected outcome in a society in which the untouchable phenomenon has been formally abolished for six decades. What is astonishing is the extent of untouchable practice that continues in the country, even in urban settings, despite the abolition after independence, the bulk of which is unreported and goes unpublished. Caste-based matrimonial alliances continue to be more the rule than the exception, even among otherwise westernized, modern, apparently caste blind youth. The agitation against caste-based quotas in education and employment that are pre-dominantly urban-based, display a very high level of caste consciousness and use overt caste-related slogans and acts of protest, thus putting a question mark on the supposed disappearance of caste in urban India (Srinivas 2003, p. 8).

It would, therefore, not be an exaggeration to argue that caste remains a powerful and potent force in Indian society, decisively shaping the contours of social and political development. Here again, Srinivas (2003, p. 459) took the view that while the caste system is dying, individual castes are flourishing. He discussed the postindependence mobilization of people on the basis of ethnicity and caste, and how this has resulted in the 'horizontal stretch' of caste. Thus, he suggested that what are called castes today, are more accurately clusters of (agnate) sub-castes that have come together for better access to such scarce resources as political power, economic opportunities, government jobs, and professional education.

It can be argued that the real key to the degree of change in the caste system is the degree of change in conditions of those who are its worst sufferers-the (ex-) untouchables. As long as the three dimensions of 
untouchable - exclusion, humiliation, and exploitation - continue to persist, we cannot declare the caste system to be dead.

\section{Caste and Identity Politics}

Identity politics is based on subjective beliefs, memory and, overt politicizations. A defining factor of identity politics is the production of a shared sense of togetherness. Identity politics is a US-based concept, arising from the black and feminist movements for equal rights and opportunities, and the resulting affirmative action policies. Identity politics was understood as a struggle for social justice. Identity-based politics have been trying to use strategic essentialism for how a sense of belonging and memories of solidarity takes place.

Gupta (2012) argues that "What is easily visible to the naked eye today is that castes, high and low, are moving both up and down the hierarchy. Further, this hierarchy is not reckoned solely in ritual terms any longer, even if that have once been the case" (Gupta 2012, p. xvi). Village economy is no longer closely tied to agriculture, and as the families of erstwhile dominant castes are mostly small farmers today, the prestige of the caste system has been roughed up as well. In other words, the village economy is rapidly moving towards the manufacturing and service sectors. To live like a landlord is no longer what it was earlier expected to be. He further says, "yes, of course, democracy has added this process, but that too would have been ineffective unless the village economy had taken the turn that it has" (Gupta 2012, p. xviii).

With the breakdown of the closed village economy and the rise of democratic politics, the competitive element embedded in caste has come to the fore. This has resulted in the collapse of the caste system but also in the rise of caste identities (Gupta 2005). Caste relations have been moving away from traditional relationships of socio-economic interdependence towards more competitive models of social interaction. There remain groups that one continues to call 'castes', but they are set in a different system. Distinguishing between caste and caste system, then, is one way to begin speaking about the structural transformation of caste. For no longer is caste defined in terms of endogamy, hereditary and relative rank (although such identifiers are implied), but as a "political fraction" in competition with "other such factions for common economic and political goal" (Leach 1960, p. 6).

Despande (2011) argued that the breakdown of the caste hierarchy has broken the traditional links between caste and profession, and released enormous entrepreneurial energies in the South. She wrote:

It is true that over time, occupational structure itself has undergone a profound change, while caste division has been relatively static. In addition, the post independence Constitution guarantees each India the freedom of choice of occupation. Thus, without fear of contradiction, one can upheld this statement for several castes, for example, members of the erstwhile warrior castes will not necessarily choose the military as a career in the present. Conversely, the military is no longer the preserve of certain castes, to the exclusion of others. It is also true that any kind of skill acquisition (for example, admission to a management or a computer course, or to a dental school) is not contingent upon one's caste status. Indeed, none of the modern occupations are determined by birth, and most are not caste-based (Despande 2011, pp. 3-4).

The erosion of the jajmani system due to the effect of the market system is really a continuity of agency of households as units of negotiation of exchange relationship. 


\section{Castes Today: Affirmative Action and Reservation Policy}

The term 'affirmative action' is typically used as the generic term covering measures of many sorts that are used to give members of traditionally disadvantaged groups a better shot at social advantage. Such measures may include encouragement, recruitment, and many non-formal types of support, as well as more formal devices, such as quotas, or reservation (Hasan and Nussbaum 2012). Among such measures, 'positive discrimination' has typically been salient - that is, giving an extra boost to members of disadvantaged groups in certain competitive contexts. Positive discrimination itself comes in many varieties: quotas or 'reservations', a preferences or priorities in hiring or awarding contracts; a specific types of numerical advantage, such as adding points to standard test scores; and finally, a much more informal and unquantifiable weighting of group membership as one among many characteristics relevant to a decision.

India pioneered the adoption of an elaborate program of affirmative action which is sanctioned in the constitution. The affirmative policies in India fall broadly into two types: antidiscriminatory or protective measures, and developmental and empowering measures. Anti-discriminatory measures include the provision of legal safeguards against discrimination. Development and empowering measures to overcome past economic and social handicaps take the forms of reservation policies for the public sector and state-supported sectors. The most significant of these measures was the provision of reservation in education and government employment for Scheduled Castes (SCs) and Scheduled Tribes (STs), and special representation rights for both these groups by way of reserved seats in legislatures (Hasan and Nussbaum 2012).

The existence of caste has been recognized negatively to identify the historically discriminated groups and eradicate caste inequality through a public reservation (quota) policy so that all members of the nation would be able to participate in public and political life as equals. In the past, the lower castes had been denied all kinds of social and economic endowment (Desai and Dubey 2011).
Hence, they had been lagging behind in the development process. Therefore, there was a need for special safeguard policies. The objective of a reservation policy is to eradicate the existing social and economic disparities in the society by introducing a quota system.

Furthermore, the justification for upholding reservations for SCs and STs came from acknowledging that these communities lacked viable marketable assets that would allow them to pursue a life of dignity in a democratic society. The SCs were denied education, and could only perform menial and polluting jobs, besides suffering from a variety of other deprivations (Gupta, 2007). In the case of the STs, it was their physical isolation that put them at a disadvantage with respect to others in society. Reservations for these communities were therefore meant to raise their marketable skills and educational standards in order to compensate for their historic disadvantages and facilitate their participation as equal citizens.

Identification of oppressed groups is done in terms of caste groups or jati. In order to realize equality, Indian government has accepted the existence of caste groups as a reality and conducts administration accordingly:

The reservation policy, based on caste, however, contains a paradox. It is notable that the kind of classification of caste group they employ is almost the same as in the colonialBrahminical caste hierarchy model. They just label it differently. SC is another name for 'harijan-dalit' castes whereas ST is for adibasi or tribes. Although they use the word 'class' for OBC, its application is based on the caste classification and the category of OBC. in fact more or less corresponds to the category of 'low caste' in the normative representational model of caste hierarchy (Tanabe, 2006, p. 771).

In the Constitution of 1990, after Jana Andolan I, Nepal tried to address existing diversity. Special provisions were made in the constitution to enact necessary acts and regulations to improve socioeconomic condition of deprived caste/ethnic groups by increasing 
their access to the national mainstream and engaging them in development and decision making processes. Periodic development plans after 1990 recognized social, economic, cultural, ethnic, linguistic, geographical, and other diversity in Nepal and initiated to address the concerns of women, Dalits and Janjatis, and people living in remote regions. Nepal's Constituent Assembly I stipulated composition of its members to have at least one-third women, and a proportional representation of Dalits and Janjatis. The result is that the country now has a highly diverse assembly that will prepare the new, post-conflict constitution.

Nepal realized that the merit based bureaucratic system of the past failed to equally and proportionately recruit people from different social backgrounds such as women, caste, ethnicity, and regions. Legal provisions of inclusion were framed only after the promulgation of the Interim Constitution of Nepal 2007. In line with the spirit of a constitution based inclusive state, priority is given to women, Dalit, Janjati, Madhesi, disabled, and people from remote areas to join the civil service. The Civil Service Act in 2007 made a special provision to reserve $45 \%$ seats for the identified groups. Affirmative action in Nepal means positive steps taken to increase the representation of women and various castes and ethnic groups regarding government jobs, education, and health service facilities as compensations or correctives for the past. Affirmative action also helps to promote disadvantaged gender, caste and ethnic groups. The constitution provides for a range of political and legal instruments to combat past inequalities through positive discrimination when recruiting people for public service jobs in the government, the army and universities. Additionally, special provisions are made for allocation of educational, economic and social facilities. This measure is considered to be a milestone in making the civil service, academic institution and other workplaces inclusive (Awasthi and Adhikary 2012). Thus, reservation policy was adopted with the objectives of creating a representative public service, mainstreaming excluded people, and narrowing down the gap between dominant and excluded groups. The major reason for the formulation of an inclusive policy in
Nepal is to increase the presence of excluded groups in public institutions and in decision-making processes.

The problem with affirmative action policies in Nepal is that it treats the entire community as a whole in a single category 'marginalized' and 'under-represented'. This means all Dalits are homogenous in terms of access to resources, economy and education. The same applies to Janjatis and Madhesis. But in reality, they do not experience the same disadvantages. An elite within the target groups is certain to benefit from these arrangements because no differentiation have been made between those who are highly marginalized and those who are better place among them. Similarly, there is no specific definition of who are Madhesis. A caste hierarchy prevails within this group and high caste Madhesis may dominate over marginalized and deprived Madhesis. This raises an important question regarding the extent to which the marginalized and disadvantaged are categorized essentially based on a caste/ethnic structure and not on discrimination and deprivation as such. In other words, the critical question is whether to use class or general social and economic criteria, thus including individuals outside the caste system, as the basis for classification or to rely principally on caste. Are the more deprived sections able to take advantage of reservation policies?

Among the most frequent criticisms of positive discrimination policies in India is that they tend to reward the best-off members of positive discrimination-eligible groups and therefore, do little or nothing for the most needy members of those groups. Deshpande (2011), based on the empirical findings of many cases from India argues that the reservation quota are based on caste identity and the advantages are taken by 'creamy layered' - the more advanced section of the 'backward castes' that are able to take advantage of preferential, policies which the most deprived sections are unable to do. The creamy layered's parents are economically and educationally better off and they have grown up in a more cosmopolitan setting than their rural counterparts. This empirical finding raises the question whether caste alone should be the qualifying reservation characteristic. In 
Nepal, for example, Dalits from remote areas see themselves as doubly disadvantaged, by a caste bias and by poverty. Compared with civil service families, it is harder for poor, rural Dalits to benefit from the reservations, given that caste and ethnicity are the only criteria. Is this truly fair for the really poor and marginalized? Are there alternatives to address the poor and marginalized? The key issue is to provide opportunity for the truly socially disadvantaged and economically marginalized. Affirmative action fails to reach its goal when it is inconsistently applied, or when its beneficiaries form a vested interest bloc on the basis of ascriptive identity alone. The kind of caste classification applied is almost the same as in the colonial Brahmin caste hierarchy model (Driks 2001), only the label is different.

The importance of an appropriately designed and transparent system for enhancing opportunities for the truly socially disadvantaged and economically marginalized groups cannot be denied. The downside of affirmative action is that it can overemphasize identity and create rifts among marginalized groups. However, to make reservations work, they need to be supported by effective affirmative policies. The reservation policy should be aimed at the really marginalized and poor people and a caste/ethnic marker is not sufficient to identify them. Affirmative action should be classbased rather than identity-based.

\section{Conclusion}

In the beginning, caste was a system for the division of labor, and social relations between different caste groups were regulated by the jajmani system. With the decline of the jajmani system and increasing livelihood diversification, caste identity became an instrument to mobilize people for economic and political gains. A basic shift took place in caste: from ritual hierarchy to identity politics, from ascribed and designated status to negotiated positions of power, from ritual definitions of roles and positions to civic and political definitions of the same (Kothari 1994). The caste system eroded at the ritual level, but emerged at the political and economic levels.

\section{Acknowledgements:}

I am grateful to Professor Chaitanya Mishra and Professor Marit Bakke for their continuous feedback, suggestion and encouragement for shaping the article into this form.

\section{References}

Appadurai, Arjun (1986). Is Homo Hierarchicus? American Ethnologists, 13(4): 745-761.

Arnold, Jeanne E. (1995). Social Inequality, Marginalization and Economic Process. In T. Douglas Price and Gary M. Feinman (eds.) Foundations of Social Inequality (87-103). New York: Plenum Press.

Awasthi, Ganga Dutta and Rabindra Adhikary (2012). Changes in Nepalese Civil Service After the Adoption of Inclusive Policy and Reform Measures. Kathmandu, Support to Participatory Constitution Building in Nepal (SPCBN)/UNDP.

Bailey, F.G. (1957). Caste and the Economic Frontier. Manchester: Manchester University Press.

Barth, Fredrik (1960). The System of Social Stratification in Swat, North Pakistan. In E.R. Leach, (ed.) Aspects of Castes in South India, Ceylon and North-west Pakistan, pp 113-148. Cambridge: Cambridge University Press.

Barth, Fredrik (1993). Balinese Worlds. The University of Chicago Press.

Berreman, Gerald D. (1967). Caste as Social Process. Southwestern Journal of Anthropology, 23(4): 351-370.

Berreman, Gerald D. (1968). The Concept of Caste. In International Encyclopaedia of Social Sciences, Vol.2, Macmillan and Free Pres. 
Berreman, Gerald D. (1972). Hindus of the Himalayas: Ethnography and Change. Berkeley: University of California Press.

Berreman, Gerald D. (1979). Caste and Other Inequities. New Delhi: Ved Prakash Vatuk.

Berreman, Gerald D (1991). The Brahmanical View of Caste. In D Gupta (ed.), Social Stratification. New Delhi: Oxford University Press.

Béteille, André (1965). Caste, Class and Power: Changing Patterns of Stratification in Tanjore Village. California: University of California Press.

Béteille, André (1991). Society and Politics in India: Essays in a Comparative Perspective. The Athlone Press Ltd.

Chatterjee, Mary Searle and Ursula Sharma (eds.) Contextualizing Caste: Post-Doumontian Approach. Sociological Review Monograph Series, Oxford: Blackwell Publishers.

Desai, Sonalde and Amaresh Dubey (2011). Caste in 21 Century India: Competing Narratives. Economic and Political Weekly, 11: 40-49.

Deshpande, Ashwini (2011). The Grammar of Caste: Economic Discrimination in Contemporary India. New Delhi: Oxford University Press.

Dirks, Nicholas B. (2001). Castes of Mind: Colonialism and Making of Modern India. Princeton: Princeton University Press.

Dumont, Louis (1980). Homo Hierarchicus: The Caste System and its Implication. Chicago: University Press Chicago.

Ghurye, G.S. (1950). Caste and Race in India. Bombay: Popular Prakashan.

Gould, Harold A. (1990). The Hindu Caste System Vol. 1. The Sacralization of a Social Order. Delhi: Chanakya Publication.

Gupta, Dipankar (ed.) (1991). Social Stratification. New Delhi: Oxford University Press.

Gupta, Dipankar (2000). Interrogating Caste: Understanding Hierarchy and Difference in Indian Society. New Delhi: Penguin Books.
Gupta, Dipankar (2005). Caste and Politics; Identity over System. Annual Review of Anthropology, 34: 409-427.

Gupta, Dipankar (2007). Towards Affirmative Action. India International Centre Quarterly, 33:150-161.

Gupta, Dipankar (2012). Foreword. In Surinder S. Jodhka (ed.) Changing Caste: Ideology, Identity and Mobility (pp xiiixviii). New Delhi: SAGE Studies in Indian Sociology, Volume 2.

Hasan, Zoya and Martha C. Nussbaum (2012). Introduction. In Zaya Hasan and Martha C.Nussbaum (eds.). Equalizing Access: Affirmative Action in Higher Education in India, United States, and South Africa. New Delhi: Oxford University Press.

Hocart, Arthur Maurice (1950). Caste: A Comparative Study. Methuen: University of Minnesota.

Hutton, J.H. (1946). Caste in India: Its Nature, Function and Origin. Bombay: Oxford University Press.

Jodkha, Surinder S. (2012). Caste: Oxford India Short Introduction. New Delhi: Oxford University Press.

Kolenda, Pauline (1981). Caste, Cult and Hierarchy: Essays on the culture of India. Meerut: Folklore Institute.

Kothari, Rajni (1994). Rise of the Dalits and the Renewed Debate on Caste. Economic and Political Weekly, 29(26): 1589-1594.

Leach, Edmund R. (1960). "Introduction: What Should We Mean by Caste?" In E.R. Leach, (ed.) Aspects of Castes in South India, Ceylon and North-west Pakistan, pp. 2-10. Cambridge: Cambridge University Press.

Leach, Edmund R. (1967). "Caste, Class and Slavery: the taxonomic problem". In Reuck, Anthony and Julie Knight (eds.) Caste and Race. London: J \& A Churchill Ltd.

Lunheim, Rolf. 1993. Desert People: Caste and community - A Rajesthani Village. University of Tronheim \& Norsk Hydro AS. 
Maquet, Jacqes J. (1970). Rwanda Castes. In Tuden, A. and L. Plotinicov (eds.) Social Stratification in Africa. New York: Free Press.

Marriott, McKim (1976). "Hindu Transactions: Diversity without Dualism". In Bruce Kapferer (ed.). Transaction and Meaning: Direction in the anthropology of exchange and symbolic behaviour, (pp109-42). Philadelphia: Institute for the Study of Human Issues.

Marriott, McKim, and Ronald B. Inden (1985). "Caste System. Encyclopaedia Britannica, 3: 982-91.

Milner, Murray (1994). Status and Sacredness: A general theory of status relations and analysis of Indian culture. Oxford University Press.

Mitra, Subrata (1994). Caste, Democracy and Politics of Community formation in India. In

Quigley, Declan (1999). The Interpretation of Caste. New Delhi: Oxford University Press.

Raheja, Gloria Godwin (1990). "Centrality, mutuality and hierarchy: shifting aspects of inter-caste Relationship in North India". In McKim Marriott (ed.) India through Hindu categories.

Sharma, K.L. (2007). Indian Social Structure and Change. Jaipur: Rawat Publications.

Sinha, Surajit (1967). "Caste in India: Its essential pattern of sociocultural integration". In Reuck, Anthony and Julie Knight (eds.) Caste and Race. London: J \& A Churchill Ltd.

Srinivas, M.N. (1962). Caste in Modern India and Other Essays. New York: Asia Publishing House.

Srinivas, M.N. (2003). 'An Obituary on Caste as a System'. Economic and Political Weekly, 38(5): 455-60.

Tambiah, Stanley J.(1972). GENERAL AND THEORETICAL: Homo Hierarchicus: An Essay on the Caste System. American Anthropologist, 74: 832-835.
Tanabe, Akio (2006). Recast(e)ing Identity: Transformation of Intercaste Relationships in Post-colonial Rural Orissa. Modern Asian Studies, 40(3): 761-796. 